\title{
Energy Production through Co-fermentation of Organic Waste and Septage in Nashik City, India
}

\author{
B.K. Gavit*, H.N. Bhange, P.M. Ingle and R.C. Purohit \\ Department of Soil Water Engineering, College of Technology \& Engineering \\ Maharana Pratap University of Agriculture \& Technology Udaipur-313 001, India \\ *Corresponding author
}

\section{A B S T R A C T}

The Urban Environment is important for all of us, not least because so many of us live in cities. Cleaner city, healthy life and a better environment are important demands for city dwellers. Due to increase in urbanization rate, population density and per capita production of solid waste is also increasing. According to MSW Rules, 2000, every municipal

Keywords

Municipal

Waste,

Nashik,

Energy,

MSW

Article Info

Accepted:

20 March 2017

Available Online:

10 April 2017 authority is responsible for setting up a waste processing and disposal facility. Approximately 50 million metric tonnes $(115,000$ metric tonnes per day) of solid waste is generated every year by the urban population in India. The per capita generation of waste in Indian cities ranges from $0.17 \mathrm{~kg}$ to $0.62 \mathrm{~kg} / \mathrm{capita} /$ day depending upon population size and its socio-economic profile. The quantity and composition of MSW vary from place to place, and bear a rather consistent correlation with the average standard of living. The Nashik city is forth largest urbanised (population) and third most industrialized city in Maharashtra after Mumbai and Pune, its also known as "Wine Capital of India". The in present case study was under taken for Nashik Municipal Corporation as Nashik Municipal Corporation (NMC) is collecting 300-350 Tons MSW per day. To overcome such problem sustainable Municipal Solid Waste Management in Nashik was planned with special reference to $3 \mathrm{R}$ strategy- Reduce, Reuse, Recycle. With better collection, transportation measures and collection efficiency. To overcome such over burden of MSW, the NMC upgraded the Khat prakalap to a capacity of 500 to 600 TPD. The NMC started pilot project on Waste to Energy on Private Public Project basis. It's one such solution through co-processing of septage (faecal sludge) with organic solid waste and generating energy to create a sustainable business model. This plant can do the treatment of up to 30 tonnes of waste daily. Resulting into generation of 3,300 $\mathrm{kWh}$ per day to be fed into Maharashtra power grid. Reduction of energy cost of NMC due to the expected revenue inflow from feeding the produced electricity into the power grid of the Maharashtra Electricity Board. It will also avoid organic waste going into the landfills of city area.

\section{Introduction}

People choose to live in urban areas so they can have a better quality of life. The world is becoming increasingly urban with $54.5 \%$ of its population living in urban areas in 2016; up from $30 \%$ in 1950 . By $2050,66 \%$ of the world's population will be urban. India is second largest nation in the world, with a population of 1.3 billion, accounting for nearly $18 \%$ of world's human population, but it does not have enough resources or adequate systems in place to treat its solid wastes (Parvathamma, 2014). Population residing in 
urban areas in India, according to 1901 census, was $11.4 \%$. This count increased to $28.53 \%$ according to 2001 census, and crossing $30 \%$ as per 2011 census, standing at $31.16 \%$. Due to rapid industrial growth, the urban population is increasing rapidly (Kumar et al., 209). Which is ultimately resulting into rapidly increase in the municipal wastages. The quantum of the Municipal Waste has also increased tremendously with improved life style and social status of the populations in urban centres (Sharholy et al., 2007). The annual waste generation has been observed to increase in proportion to the rise in population and urbanization and issues related to disposal have become challenging as more land is needed for the ultimate disposal of these solid wastes (Idris et al., 2004). Rapid urban population growth has resulted in a number of land-use and infrastructural challenges, including municipal solid-waste management. National and municipal governments often have insufficient capacity or funding to meet the growing demand for solid-waste management services

Approximately 50 million metric tonnes (115,000 metric tonnes per day) of solid waste is generated every year by urban population in India. The per capita waste generation in Indian cities ranges from 0.17 $\mathrm{kg}$ to $0.62 \mathrm{~kg} / \mathrm{capita} /$ day depending upon population size and its socio-economic profile. Segregation at source, collection, transportation, treatment and scientific disposal of waste is largely insufficient leading to degradation of environment and poor quality of life. India is having 29 states and 7 Union territories. Among these states, Maharashtra $(22,200$ TPD or 8.1 million TPY), West Bengal (15,500 TPD or 5.7 million TPY), Uttar Pradesh (13,000 TPD or 4.75 million TPY), Tamil Nadu (12,000 TPD or 4.3 million TPY) Andhra Pradesh (11,500 TPD or 4.15 million TPY) generate the highest amount of MSW (Aannepu, 2012).
Where as in case of Union Territories, Delhi (11,500 TPD or 4.2 million TPY) generates the highest and Chandigarh (486 TPD or 177,400 TPY) generates the second highest amount of waste.

The composition of urban MSW in India is $51 \%$ organics, $17.5 \%$ recyclables (paper, plastic, metal, and glass) and $31 \%$ of inert. The moisture content of urban MSW is $47 \%$ and the average calorific value is $7.3 \mathrm{MJ} / \mathrm{kg}$ (1745 kcal/kg). The composition of MSW in the North, East, South and Western regions of the country varied between $50-57 \%$ of organics, $16-19 \%$ of recyclables, $28-31 \%$ of inerts and $45-51 \%$ of moisture. The calorific value of waste varied between $6.8-9.8 \mathrm{MJ} / \mathrm{kg}$ (1,620-2,340 kcal/kg (Parvathamma, 2014).

Solid waste is the unwanted or useless solid materials generated from combined residential, industrial and commercial activities in a given area. Municipal solid waste consists of household waste, construction and demolition debris, sanitation residue, and waste from streets. This garbage is generated mainly from residential and commercial complexes. With rising urbanization and change in lifestyle and food habits, the amount of municipal solid waste has been increasing rapidly and its composition changing. Solid Waste Management (SWM) is an organized process of storage, collection, transportation, processing and disposal of solid refuse residuals in an engineered sanitary landfill (Dalvi et al., 2016).

Depending upon source, MSW is categorized into residential or household waste which arises from domestic areas from individual houses; commercial wastes and/or institutional wastes which arise from individually larger sources of MSW like hotels, office buildings, schools, etc.; municipal services wastes which arise from 
area sources like streets, parks, etc. MSW usually contains food wastes, paper, cardboard, plastics, textiles, glass, metals, wood, street sweepings, landscape and tree trimmings, general wastes from parks, beaches, and other recreational areas. Some approximate time to degenerate the litter is shown in Table 1.

Solid waste management is one among the basic essential services provided by municipal authorities in the country to keep urban centres clean (Usnani, 2006). Waste is any material/liquid that is thrown away as unwanted. As per physical properties, waste can be categorized as:

\section{Solid waste}

Any waste other than human excreta, urine and waste water, is called solid waste. Solid waste consist of house sweeping, kitchen waste, garden waste, cattle dung and some waste from cattle sheds, agro waste, broken glass, metal, waste paper, plastic, cloths, rubber, waste from markets and shopping areas, hotels, etc. On the basis biodegradability, solid waste is further categorised as:

\section{Biodegradable}

Waste that are completely decomposed by biological processes either in presence or in absence of air are called biodegradable. e.g. kitchen waste, animal dung, agricultural waste etc

\section{Non-biodegradable}

Waste which cannot be decomposed by biological processes is called nonbiodegradable waste. These are of two types:

Recyclable: waste having economic values but destined for disposal can be recovered and reused along with their energy value. e.g. plastic, paper, old cloth etc.

Non-recyclable: Waste which do not have economic value of recovery e.g. tetra packs, carbon paper, thermo coal etc.

\section{Liquid waste}

Used as well as unwanted water is called waste water

Black Water: Waste water generated in the toilet is called "Black water". It contains harmful pathogens

Greywater: Waster water generated in the kitchen, bathroom and laundry is called "Greywater". It may also contain pathogens.

\section{Location of study Area}

The present study was taken for Nashik Municipal Corporation (NMC). Nashik city is one of the holy places located on bank of Godavari (Vridha Ganga). It is also referred as the "Wine Capital of India". The Nashik is forth largest urbanised (population) area and third most industrialized city in Maharashtra after Mumbai and Pune. Nashik has a peculiarity of its own due to its mythological, historical, social and cultural importance The NMC is having about $259 \mathrm{~km}^{2}$ area divided into 6 divisions.

Due to urbanization and industrialization of city Nashik Municipal Corporation (NMC) is collecting 300-350 tons MSW per day. To overcome such problem sustainable Municipal Solid Waste Management in Nashik was planned with new plant. As per DPR 2007, per capita MSW quantity has been estimated to reach $400 \mathrm{~g} /$ day by 2011. This type of growth rate may be witnessed in the current decade also. Keeping above factors in view the projected quantity of MSW is 750 
TPD by the year 2015 and 1628 TPD by year 2031.

Analysis of city waste carried out recently, reveals $37.8 \%$ easily compostable (short-term biodegradable) materials, $19.50 \%$ hard lignite's and long term biodegradables and $16.20 \%$ textiles, plastic rubber etc (Gadakha et al., 2013). These last two components having $35.70 \%$ content in the MSW have become a major cause of concern. Looking to the recent trend of changing waste characteristics, increasing quantities of combustible materials and infrastructural bottlenecks, it became essential to upgrade overall MSW collection, storage, transportation and processing through integrated technological facility at Khat Prakalp site. This plant came into operation in 2000. However, this plant was small and could not deal with the entire 350 TPD waste reaching the plant and a backlog of $>2.50$ lakh MT waste was generated, which was piled put in two heaps close to the plant. Mounting heaps of high volumes of low density waste is a common scene around each compost plant. This has necessitated re-thinking of the integrated technological approach to solve MSW disposal problem towards a total solution in a sustainable manner. Nashik is only city in Maharashtra which has taken lead towards scientific management of MSW in abidance of MSW rules 2000.

Hence considering the future thrust NMC planned within the framework of "International Climate Initiative" of Federal Ministry for Environment, Nature Conservation, Building and Nuclear Safety, Germany (BMUB) GIZ is supporting Nashik Municipal Corporation in implementation of an innovative "Waste to Energy" project in the city.

\section{Objective of pilot project}

The main objective of the waste to energy pilot project is to demonstrate the innovative concept of combined treatment of black water and organic solid waste (co-fermentation) for generation of renewable energy. To produce clean energy by using the energy content of wastewater/sludge and organic waste in Nashik. The methane generated can be utilized for the production of electricity through a combined heat and power plant. The proposed innovative technology involves co-fermentation of the organic degradable part of municipal solid waste and fresh black water from toilets.

\section{Approach}

The approach of this project is a participatory process of converting waste to energy. The participatory process ensures involvement of all stakeholders NMC, public representatives, hotel industry, technical experts and engineers.

\section{Approach and Methodology}

Within the framework of "International Climate Initiative" of the Federal Ministry of Environment, Nature Conservation and Nuclear Safety of Germany, GIZ is supporting NMC in implementation of "Waste to Energy" project. The project involves construction of a waste-to-energy plant which will consume food and vegetable waste from up to 1300 restaurants and hotels, as well as black water collected from about 200 community toilets in Nashik. In total it would consume between 10 to 15 tons of organic waste and 10 to 20 tons of black water each day.

\section{Site selection}

The Waste to Energy project in Nashik is being implemented in cooperation with NMC. The project area has been shortlisted among various other cities such as Delhi, Raipur and Nashik, as Nashik offered the best conditions for project implementation due to the 
availability of secured input material (organic waste from hotels and black water from toilet complexes) and their utilization as well as the existing infrastructure. Even though technology of waste to energy (WTE) projects has been proven worldwide, its viability and sustainability is yet to be to be demonstrated and established in the country. NMC will also make provisions for utilization of the produced energy into the state power grid.

The total project cost is Rs. 8,02,79,658/-, of which $80 \%$ is being provided by German Federal Ministry for the Environment, Nature Conservation, Building and Nuclear Safety (BMUB) under International Climate Initiative (IKI), while the rest has been financed by the contractor, Vilholi Waste Management Systems Pvt. Ltd. The NMC and GIZ laid foundation stone for Waste to Energy project at Nashik to mark the start of plant construction of the Waste to Energy plant. Dr. Praveen Gedam, Commissioner, Nashik and Mr. Dirk Walther, Project Director, GIZ, laid the foundation stone on $4^{\text {th }}$ Sept. 2015 at the project site - Pathardi, near the solid waste management facility of Nashik.

\section{Feasibility study}

The main factors for determining the techno economic viability of WTE projects are quantum of investment, scale of operation, availability of quality waste, statutory requirements and project risks. A feasibility study was assess to taste the possibilities for combining liquid and solid organic waste flows in Nashik, their potential for material and energy recovery and ensuring that secured input of substrate is available.

\section{Availability of input material flows}

The overall performance of the Biomethanation plant is greatly influenced by the input feed specification and the plant requires segregated biodegradable MSW (e.g. hotel and restaurant waste, market waste) for optimal plant performance rather than unsegregated MSW. The homogeneity of the feed stock is an important parameter from the efficiency point of view. Therefore special care has been taken through detailed study and analysis for ensuring continuous supply of input material flows. Based on the feasibility study, a survey of commercial establishments and community toilets in the city and a study on balance of inputs and outputs from admixtures of organic waste and black water from community toilets were carried out.

The study on characterization and quantification of solid waste generated in hotels in Nashik revels that there are around 1300 establishments in the city from where organic waste for the project can be made available through a dedicated collection and transportation system.

CIDCO, Nashik East and Nashik West divisions are close to the site selected for the waste to energy plant and having maximum number of hotels with high potential of organic waste generation. The total amount of organic waste generated in these establishments in approx. 25 to 30 tons per day. Apart from these hotels large amount of raw organic waste material is also available from 6 main vegetable markets.

\section{Study on wastewater streams from selected Community Toilet Complexes (CTC) in Nashik for black water}

The flow patterns of selected septic tanks from CTCs were assessed bi-hourly for four consecutive days in order to simulate the hydraulic load of the septic tanks inflow. The survey of the study shows that sufficient quantity of black water is available throughout the year for sustainable operation of the plant. NMC owns around 400 
community toilet complexes within the city and which ensures the source for black water as second input substrate.

Considering the size of the septic tanks of CTC's and usage pattern in Nashik availability of black water will not be an issue for the plant. An effective and highly mechanized system for collection and transportation of black water from CTC's to the plant is planned to ensure the reliable and regular flow of input materials.

\section{Balance of input and output study at different admixtures}

The detailed analysis of the physico-chemical and biological characterization for organic waste from hotels and black water from septic tanks of community and public toilets was carried out by Birla Institute of Technology, Pilani, Goa (BITS Pilani Goa) for assessing the methane generation potential. The anaerobic co-digestion of organic waste and black water was carried out for different samples as well as admixture from 1:1, 1.5:1, $2: 1,1: 1.5$ and $1: 2$. The various proportions of organic wastes, black water and admixture were examined for energy yielding characteristics through their Biomethanation Potential (BMP). Samples from six divisions from community toilet complexes and selected hotels were collected in four months interval to accommodate the seasonal variations. The methodology and results of the study are shown below:

Admixture of organic waste to black water at $1: 1.5$ ratios gives better biogas production in sample 1 whereas in sample 2 ratio 1:2 gives highest yield. The biogas yield of these samples is in a range of 1600 to 2300 cum/day. If more food waste is added to the samples the production of biogas decreases. Therefore it has been suggested to use the mixture of organic waste and black water in the proportion of 1:1.5 (12 TPD food waste and 18TPD black water). However it has been left to the operator to select the best suitable ratio based on requirements and studies conducted in the city.

Addition of wastewater from septic tanks of CTCs ensures regular supply of sulphur and other trace elements $(\mathrm{Ni}, \mathrm{Co}, \mathrm{Mo}, \mathrm{Fe}, \mathrm{Zn}, \mathrm{Cu}$, $\mathrm{Mn}$ etc.) for bacterial growth in the digester. In domestic wastewater, there is usually no lack of such substances as they originate from urine and faeces in sufficient concentrations. Digesters are prone to failure in absence of supply of these trace elements.

\section{Brief description of the projected plant}

The plant is designed for an input of 10 to 20 TPD black water and 10 to 15 TPD organic wastes. The daily amount of digested slurry is about 30 tons. The ideal ratio for mixture as per the balance input and output study conducted by Birla Institute of Pilani, Goa is 12 TPD black water and 18 TPD organic wastes for maximum biogas production. The digest can be safely post-treated in the existing aerobic composting facility. The required addition of water to the composting process could then be made redundant. Alternatively, the direct application on nearby agricultural areas is feasible. The methane produced in the plant is converted to electricity in the combined heat and power plant. The daily production of biogas is expected to be $1600 \mathrm{~m}^{3}$ to $2100 \mathrm{~m}^{3}$, which can generate about $3000 \mathrm{kWh}$ electricity per day with the power for internal use already deducted. In return the plant operator will supply a "guaranteed energy" daily subject to a minimum of $1150 \mathrm{kWh}$ electricity to NMC free of cost. This electricity will be fed to the MSEB grid which can be utilized by NMC to avail rebate on monthly electricity bills. Any additional power generated by operator will be source of additional revenue for the operator. Excess heat would also be used to pre-heat and conditioning of the incoming 
waste water, thus accelerating the digestion process of the waste mixture.

The key technical component of the projected plant is a stirred anaerobic reactor with following components.

- Receiving station for organic waste

- Pre-treatment

- Pasteurization (optional)

- Gas storage with flare (in case of excess gas)

- CHP with gas pre treatment

- Heat distribution system

- Transfer of digestate

The plant should be designed in such a way that it should be robust and construction should be based on local conditions. With respect to keep the maintenance cost low the introduced technical design uses mainly machinery made in India. The process flow chart is shown below:

\section{Model Operation}

In addition to availability of input material, reliable marketing for the final product is one of the main prerequisites for a long term financially viable operation of plant. Therefore it has been ensured through the tendering process that provision of services should be "one- stop- solutions". The project will be implemented through on Design, Finance, Built, Operate and Transfer
(DFBOOT) mode through the involvement of a private player for ensuring additional investment required. Involvement of private players will also ensure sustainable operation and maintenance of the plant. The planning and implementation concept will be documented. The PPP approach opens possibilities to develop and replicate sustainable Waste to Energy plants through "fair" contract arrangements and proper contract management. The operation of the plant will be with the contractor for a period of 10 years and NMC will pay monthly tipping fees for collection and transportation of 30 TPD of waste flows from city to the site and the operation of the plant. In return the plant operator will guarantee the supply of daily minimum of $1150 \mathrm{KWh}$ electricity to NMC free of cost through supply to the grid and in return NMC will get rebate on monthly electricity bills. Any additional power generated by operator will be source of additional revenue for the operator.

\section{Capacity Building Strategy}

A capacity building strategy is designed for NMC staff and the future operator in the fields of human resource development and organizational development. It includes onsite trainings, setting up of an onsite laboratory and lab protocols for various tests and analysis, financial management etc.

Table.1 The type of litter generate and the approximate time it takes to degenerate

\begin{tabular}{|l|c|}
\hline Type of litter & Approx. Time to degenerate the litter \\
\hline $\begin{array}{l}\text { Organic waste such as vegetable and } \\
\text { fruit peels, leftover foodstuff, etc. }\end{array}$ & a week or two. \\
\hline Paper & $10-30$ day \\
\hline Cotton cloths & $2-5$ months \\
\hline Woods & $10-15$ years \\
\hline Woollen items & 1 year \\
\hline $\begin{array}{l}\text { Tin, Aluminium and other materials } \\
\text { such as cans }\end{array}$ & $100-500$ years \\
\hline Plastic bags & One million year? \\
\hline Glass bottles & Undetermined \\
\hline
\end{tabular}


Table.2 Total No. of commercial establishments in Nashik

\begin{tabular}{|l|l|l|}
\hline & Administrative Division & Commercial establishment \\
\hline 1 & CIDCO & 225 \\
\hline 2 & Nashik East & 274 \\
\hline 3 & Nashik West & 219 \\
\hline 4 & Nashik Road & 309 \\
\hline 5 & Panchavati & 273 \\
\hline 6 & Satpur & 84 \\
\hline & Total & $\mathbf{1 3 8 4}$ \\
\hline
\end{tabular}

Table.3 Total No. of Community Toilet seats in Nashik

\begin{tabular}{|l|c|}
\hline \multicolumn{1}{|c|}{ Area } & Public Toilets seats \\
\hline Nashik East & 1144 \\
\hline Nashik west & 537 \\
\hline Satpur & 650 \\
\hline CIDCO & 495 \\
\hline Nashik Road & 1108 \\
\hline Panchvati & 1634 \\
\hline Total & $\mathbf{5 5 6 8}$ \\
\hline
\end{tabular}

Table.4 Biomethanation Potential (BMP) for different admixture

\begin{tabular}{|c|c|c|c|c|c|c|c|}
\hline & & & \multicolumn{2}{|c|}{ Sample 1 } & \multicolumn{2}{c|}{ Sample 2 } \\
\hline Ratio & $\begin{array}{l}\text { Organic } \\
\text { Waste } \\
\text { (TPD) }\end{array}$ & $\begin{array}{l}\text { Black } \\
\text { water } \\
\text { (TPD) }\end{array}$ & $\begin{array}{l}\text { Total input } \\
\text { (TPD) }\end{array}$ & $\begin{array}{l}\text { Biogas yield } \\
\left(\mathrm{m}^{3} / \mathrm{day}\right)\end{array}$ & $\begin{array}{l}\text { Specific gas } \\
\text { yield (Methane } \\
\left.-\mathrm{m}^{3} / \mathrm{day}\right)\end{array}$ & $\begin{array}{l}\text { Biogas } \\
\text { yield } \\
(\mathrm{m} 3 / \mathrm{day})\end{array}$ & $\begin{array}{l}\text { Specific gas } \\
\text { yield (Methane - } \\
\left.\mathrm{m}^{3} / \mathrm{day}\right)\end{array}$ \\
\hline 1 & 15 & 15 & 30 & 2272 & 1363 & 1372 & 823 \\
\hline $1.5: 1$ & 18 & 12 & 30 & 2128 & 1277 & 1423 & 854 \\
\hline $2: 1$ & 20 & 10 & 30 & 1555 & 933 & 1415 & 849 \\
\hline $1: 1.5$ & 12 & 18 & 30 & 2269 & 1361 & 1326 & 795 \\
\hline $1: 2$ & 10 & 20 & 30 & 2248 & 1348 & 1643 & 986 \\
\hline
\end{tabular}

(Source: Yadav et al., )

Fig.2 Schematics of project

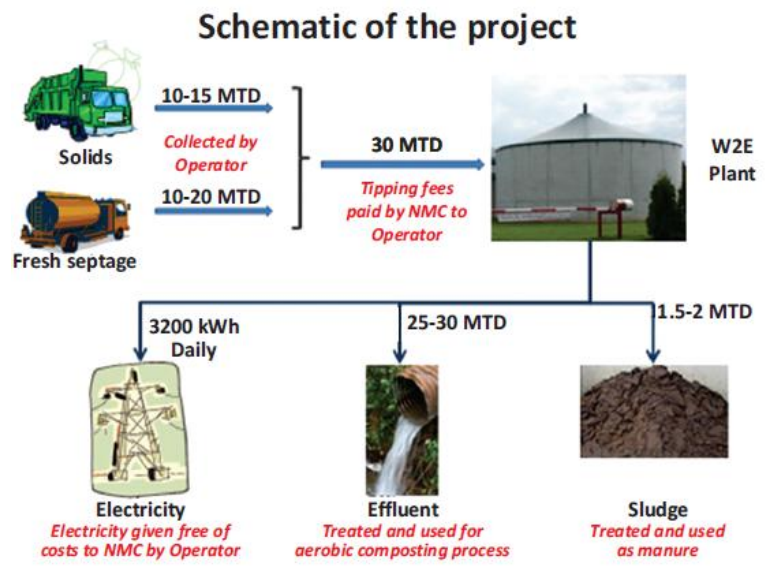


Fig.1 Location Map of the study area

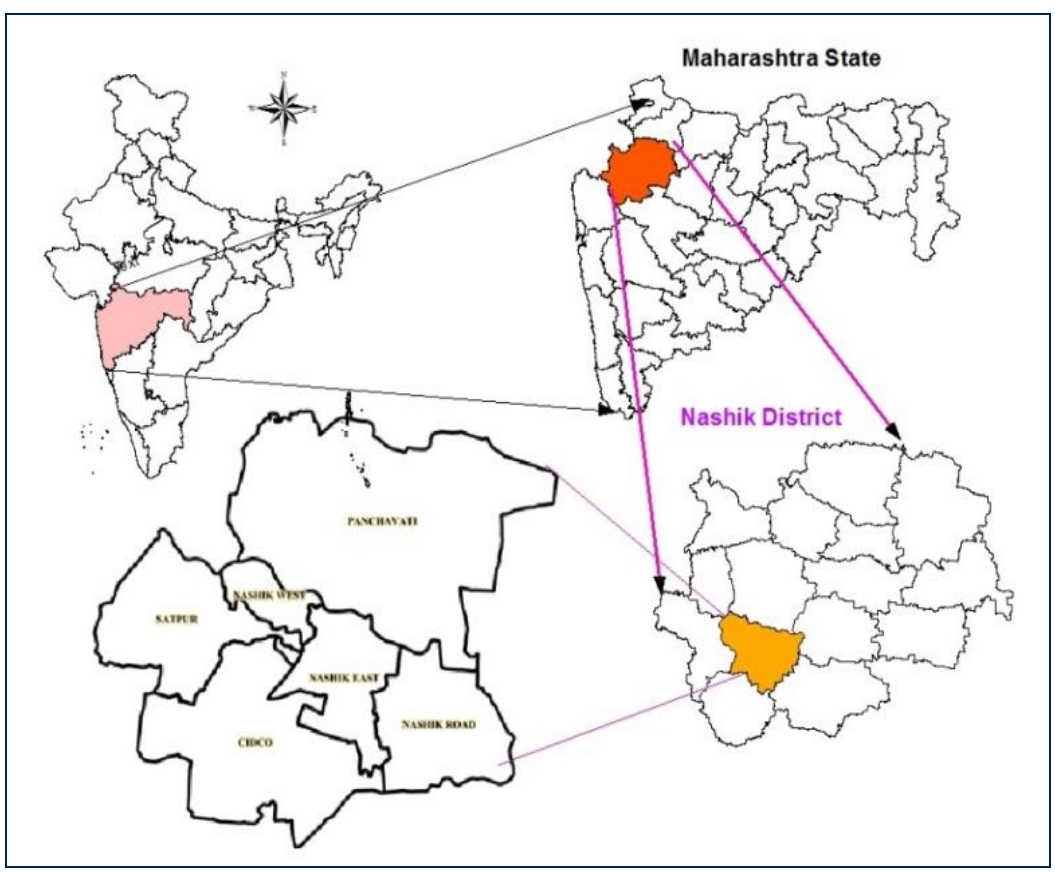

Fig.3 Process flowchart for proposed waste to energy plant in Nashik

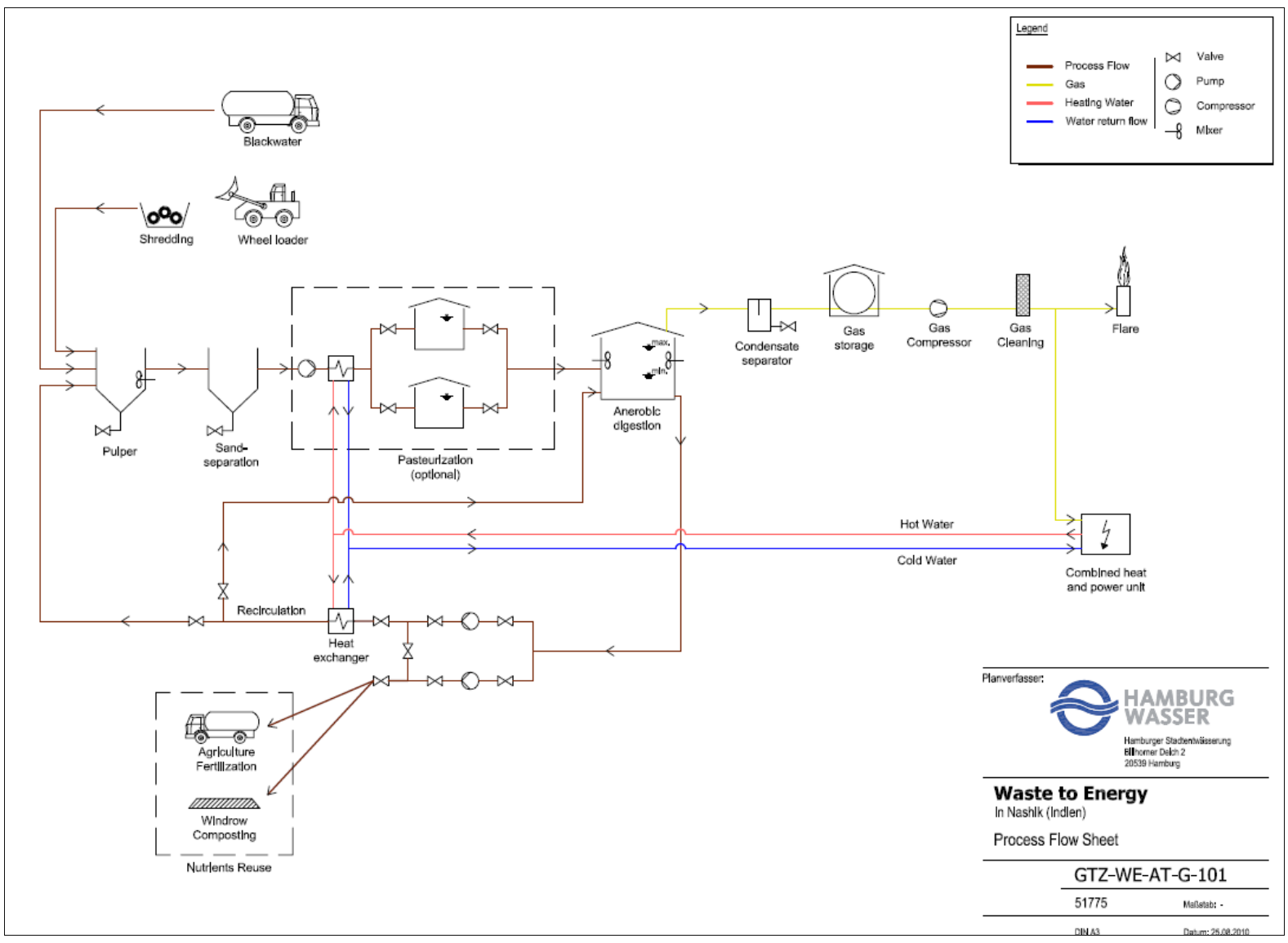


In conclusion, with the increasing population, the amount of waste is increasing day by day which is not properly manageable. It is expected that such pilot project will not only reduce the GHG emissions of NMC but also contribute to the improvement of current practices in solid waste management and waste water management by demonstrating financially viable and technically feasible solutions in line with climate change goals of Government of India. Learning's from this project may help in up-scaling this or adjusted approaches within the framework conditions of Indian cities. The innovative pilot project is in the line with Government of India's endeavour to encourage $\mathrm{WtE}$ projects for urban waste. Combined treatment of two major waste sources: Septage and Biodegradable waste. Electricity bills of the city reduce through generation of energy from renewable source. Less financial resources required for treatment of waste. Convincing model for cooperation with private sector, in return the plant operator will guarantee the supply of daily minimum of $3,300 \mathrm{kWh}$ electricity to the Maharashtra Power Grid, which will be accessible for NMC free of cost. In MSW there is a strong case of private sector participation in this area and private sector can come with its expertise, technology, capital, improved and efficiently managed service. Public participation is of paramount importance and can provide big results if seek properly.

\section{References}

Annapurna Shaw (2017). The challenges of urbanization in India: Towards a more humane urbanism. Conference on 'Political Economy of Emerging Market Countries: The Challenges of Developing More Humane Societies' January 2-4, 2017, Santiniketan, West Bengal. 2-22.

Annepu R. K. (2012). Sustainable Solid Waste Management in India. M. Sc
Thesis. Department of Earth and Environmental Engineering $\mathrm{Fu}$ Foundation School of Engineering and Applied Science Columbia University in the City of New York.

Dalvi V.D., P.G. Gaikwad and A.B. Saner (2016). Public Private Partnership in Solid Waste Management in Nasik City. International Journal of Latest Engineering Research and Applications. Vol. 1 (5): 05-15.

Dimple Vij (2012) Urbanization and solid waste management in India: Present practices and future challenges. Procedia - Social and Behavioral Sciences Vol. 37: 437 - 447.

Gadakh B.L, D.G. Gaikwad, R.G. Jaybhae and S.D. Pardeshi (2013). An Assessment Of Solid Waste Management: A Case Study of Nashik Municipal Corporation. South Asian Journal of Marketing and Management Research. Vol.3 (6): 56-63.

Idris, A., B. Inane and M.N. Hassan. (2004). Overview of waste disposal and landfills/dumps in Asian countries. Material Cycles and Waste Management. Vol. 16: 104- 110.

Kumar S., J.K. Bhattacharyya, A.N. Vaidya, Tapan Chakrabarti, S. Devotta and A.B. Akolkar (2009). Assessment of the status of municipal solid waste management in metro cities, state capitals, class I cities and class II towns in India: An insight. Waste Management. Vol. 29: 883-895.

Parvathamma G.L. (2014). An analytical study on problems and policies of solid waste management in India-Special Reference to Bangalore City. Journal of Environmental Science, Toxicology and Food Technology. Vol.8 (10): 6-15.

Project report on Waste to Energy for Urban India through Co-fermentation of Organic Waste and Septage by Augustin, Dr. Kim (HAMBURG 
WASSER), Giese, Thomas Yadav, J.M., R. Dube, Dirk Walther and R. (HAMBURG WASSER) and Dube, Dr. K. Pawar. Waste to Energy through CoRegina (GTZ). fermentation of Organic Waste and

Sharholy, M., K. Ahmad, R. Vaishya and R. Gupta. (2007). Municipal solid waste Septage in Nashik: A Close the Loop Cycle Approach. The Deutsche characteristics and management in Allahabad, India. Waste Management. Vol. 27 (4): 490-496.

Usnani,P.U., 2006. India Infrastructure Report 2006.161-189. Gesellschaft für Internationale Zusammenarbeit (GIZ) GmbH, New Delhi, India. $4^{\text {th }}$ Edition E-Proceedings Iconswm 2014 Hyderabad.Edited by Sadhan K Ghosh. 369-375.

\section{How to cite this article:}

Gavit, B.K., H.N. Bhange, P.M. Ingle and Purohit, R.C. 2017. Energy Production through Cofermentation of Organic Waste and Septage in Nashik City. Int.J.Curr.Microbiol.App.Sci. 6(4): 2788-2798. doi: https://doi.org/10.20546/ijcmas.2017.604.322 